\title{
Effect of Physical Aging on the Stress and Birefringence Relaxation Behaviors in Polycarbonate Glass
}

\author{
Yoshihiro Tomono, Hiromu SAITO, and Takashi InOUE \\ Department of Organic and Polymeric Materials, Tokyo Institute of Technology, \\ 2-12-1 Ookayama, Meguro-ku, Tokyo 152-8552, Japan
}

\begin{abstract}
The effect of physical aging on stress and birefringence relaxation behaviors in polycarbonate (PC) glass was investigated. The birefringence relaxed monotonically at the glass transition-to-rubbery plateau region for the nonaged PC, suggesting that chain orientation relaxes in a single relaxation process in this region. On the other hand, stepwise relaxation behavior was observed in birefringence for the aged PC. The birefringence relaxation curves at various temperatures for the aged PC could not be superimposed by horizontal shift. The complicated relaxation behavior could be caused not only by the physical aging but also by the rejuvenation of enthalpy during the relaxation measurement.
\end{abstract}

Key Words: Physical aging / Polycarbonate / Stress relaxation / Birefringence / Enthalpy relaxation

\section{ポリカーボネートのphysical agingと 応力・複屈折緩和挙動}

\author{
伴野 佳弘, 斎藤 拓, 井上 隆
}

(原稿受理 : 1998年8月24日)

\section{1.はじめに}

非晶性高分子の応力緩和挙動は, 時間・温度換算則により 「ガラス領域」,「ガラス転移領域」,「ゴム状平坦領域」、「流 動領域」に至る全ての時間領域において，一本の重ね合わせ 曲線で表わされる11)・「ゴム状平坦領域」において緩和時間は 分子量の3乗に比例する. 兴れは隣接鎖が形成する仮想のチ ューブの中を高分子鎖か蛇のようにほふくく運動 (reptation) することを仮定したチューブモデルにより説明されている2． また，「ガラス転移領域」では応力緩和曲線の傾きが-1/2に なり，弚れは粘性的性質を持ったビーズと弾性的性質を持っ たバネで記述したバネービーズモデル (ラウスモデル) によ り説明されている3 緩和については下記のphysical agingとの関連のもとに重大な 未解決問題か残されている. 通常「ガラス転移領域」の緩和 挙動はガラス転移温度 $T_{g}$ 以下での応力䋧和測定の結果, 特に 長時間側の測定值をもとに評価されている.一方, 高分子ガ ラスは非平衡状態にあり， $T_{g}$ 以下で熱処理するとphysical agingにより, エンタルピーが緩和したり比容積が減少（緻 密化) することが知られている.なお, エンタルピーの緩和 は示差熱走査熱量測定 (DSC) においてagingに伴い吸熱ピ 一クが出現することから ${ }^{612)}$ ，また緻密化についてはディラ

東京工業工業大学 有機材料工学科

₹ 152-8552 東京都目黑区大岡山2-12-1
トメトリーにおいて密度が低下すること ${ }^{13)}$, 14) や陽電子消滅 法において自由体積が低下すること战, 16) により確認されて いる.このphysical agingは $T_{g}$ 以下での応力緩和測定中に進行 するはずである．乥れが「ガラス転移領域の応力緩和挙動」 に及ぼす影響を明らかにすることが, 本研究の課題である . 一軸伸長後の複屈折緩和の結果より, 分子配向の見地て緩

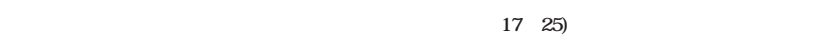
フェノールー Aポリカーボネート (PC) の応力緩和と複屈折 緩和を同時に測定して, 光れらの時間・温度依存性の結果か ら「ガラス転移領域」での分子の配向緩和挙動を論じる .さ らに, 応力・複屈折緩和中のphysical agingに関する知見を温 度変調DSCにより得ると共に, physical agingさせたPC試料 の応力・複屈折緩和挙動も調べることにより，「ガラス転移 領域」における分子配向緩和挙動とphysical agingの関係につ いて考察する .

\section{2. 実験}

$\mathrm{PC}$ 試料として帝人 (株) 社製パンライト $\left(T_{g}=147^{\circ} \mathrm{C} \square\right.$ $M \mathrm{w}=34,600, M \mathrm{w} / M \mathrm{n}=1.2)$ を用いた. $\mathrm{PC}$ 試料を $240^{\circ} \mathrm{C}$ で溶融

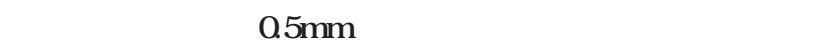
quenched試料を得た，光れを約 $50 \mathrm{~mm} \times 5 \mathrm{~mm}$ の短冊状に切断 した . quenched試料を, $127^{\circ} \mathrm{C}\left(=T_{g}-20\right)$ で85時間熱処理し てaged試料を得た。 
Fig.1に応力・複屈折緩和同時測定装置を示す ${ }^{18), 19)}$. 装置は 応力測定装置と複屈折測定装置の $2 つ$ 部分から成る . 所定 の温度に設定した恒温槽中の力ゲージの留め金に短冊状試料 を固定する . パルスモーターを用いて試料を上下方向に高速 一軸延伸させて, 一定歪み $\varepsilon$ を印加させた後の応力緩和測定 を行った .

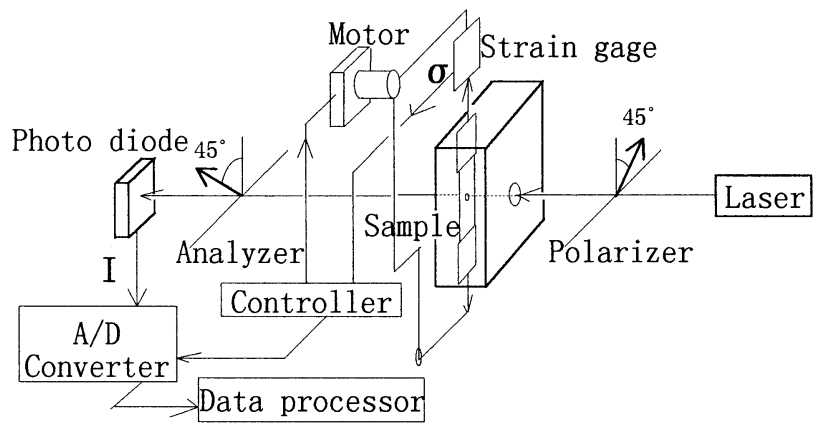

Fig.1 Apparatus for simultaneous measurement of tensile stress and birefringence relaxation after uniaxial stretching.

複屈折緩和と応力緩和の同時測定を行うために, 試料に He-Neレーザー (波長632.8nm) を照射した. 偏光子の偏光 方向と試料の伸長方向を45度に, また偏向子と検光子を90度 に設定した . 検光子を透過した光はフォトダイオードで検出 して, 応力緩和中の透過光強度 $I$ の変化を測定した . 複屈折 $\Delta n$ は次式により求めた

$$
\mathrm{I}=\mathrm{C} \sin \left(\frac{\pi \Delta \mathrm{n} \cdot \mathrm{d}}{\lambda}\right)
$$

ここで, $d$ は試料の厚みである . なお，印加歪みは温度によ り変えた $\left(T_{g}\right.$ 以下では約 $0.5 \%, T_{g}$ 以上では約1.0\% $)$ ので， 複屈折值として $\Delta n$ を歪みで割った值 $\Delta n / \varepsilon$ を用いた .

温度変調DSC測定はExster 6200 (セイコーインスツルメ ンツ (株) 社製) を用いて窒素ガス䨌囲気中で行った . 測 定に用いた試料重量は約10mgである. 温度変調D SC 測定 では次式で表わされるように, 試料に一定速度の昇温過程 で交流の温度波が重なるように付加的に熱が試料に印加さ れる(2), 26), 27).

$$
T=T_{0}+B t-A \sin (2 \pi f t)
$$

ここで $T_{0}$ は測定開始温度,$B$ は昇温速度,$t$ は時間, $A$ は温度 変調の振幅, $f$ は温度変調の周波数である. 本測定では, $B$ $=5^{\circ} \mathrm{C} / \mathrm{min}, A=2^{\circ} \mathrm{C}, f=0.02 \mathrm{~Hz}$ に設定した . 得られた熱量曲線 をFourier変換して, 求められる熱量の可逆成分からガラス 転移が, 不可逆成分からエンタルピー緩和の回復に伴う吸熱 ピークが分離評価できる. また熱量曲線を移動平均法で平均 化することにより, ガラス転移と吸熱ピークの和である全熱 量曲線を求めた . これは, 従来のDSC法で得られる熱量曲線 と等価である。

\section{3. 結果と考察}

quenched試料の緩和弾性率 $E(t)$ をFig.2に示す. $T_{g}$ 以下の短 時間域において弾性率が約109Paの平坦なガラス領域が見ら

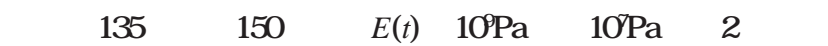
急激に低下するガラス転移領域が見られる. $150^{\circ} \mathrm{C}$ から $160^{\circ} \mathrm{C}$ では約107Paのゴム状平坦領域が見られる．さらに高温，長 時間測定により流動領域か現れ， $E(t)$ が再び急激に低下する。 これらは非晶性高分子に典型的な応力緩和挙動である11.

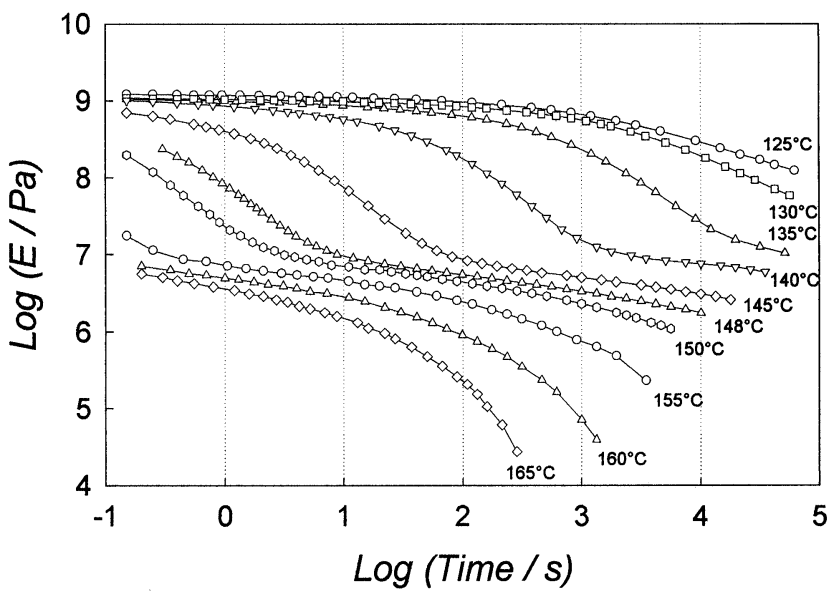

Fig.2 Relaxation modulus $E(t)$ of quenched PC.

Fig.2で示した応力緩和と同時に測定された緩和複屈折 $\Delta n(t) / \varepsilon$ をFig.3に示す . 低温では $E(t)$ と同樣に $\Delta n(t) / \varepsilon$ も平 坦である $E(t)$ でガラス転移領域が見られる測定温度・時間 において $\Delta n(t) / \varepsilon$ は緩やかに低下するが， $E(t)$ に見られるよ うなガラス転移領域とゴム状平坦領域の間の明確な屈曲は見 られず, 連続的に低下している. $\Delta n(t) / \varepsilon$ の緩やかな低下の 後で, 流動領域に特徵的な $\Delta n(t) / \varepsilon$ の急激な低下が見られる。

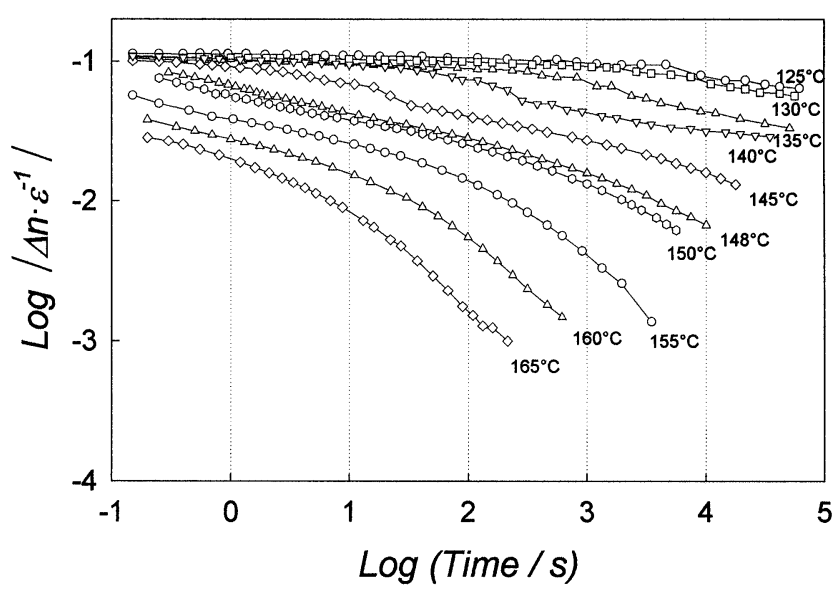

Fig.3 Relaxation birefringence $\Delta n(t) / \varepsilon$ of quenched PC. 
$E(t)$ と $\Delta n(t) / \varepsilon$ の重ね合わせ曲線 $E\left(t / a_{T}\right)$ と $\Delta n\left(t / a_{T}\right) / \varepsilon$ を Fig.4 に示す .なお , シフトファクター $a_{T}$ は $E(t)$ の重ね合わせによ り求め, 兴の值を用いて $\Delta n(t) / \varepsilon$ の重ね合わせを行った . $E(t)$ と $\Delta n(t) / \varepsilon$ ともに良好に重ね合わせを行うことができた . シフトファクターの温度依存性はFig.4の挿入図に示した . シフトファクター $a_{T}$ の温度依存性に対してWLF式"

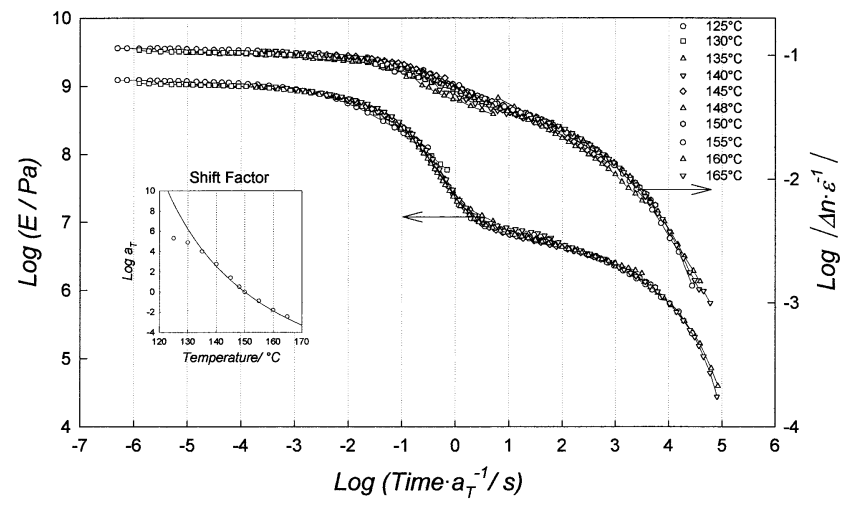

Fig.4 Master curves of relaxation modulus $E\left(t / a_{T}\right)$ and relaxation birefringence $\Delta n\left(t / a_{T}\right) / \varepsilon$ of quenched PC; reduced at $150^{\circ} \mathrm{C}$

$$
\log a_{T}=\frac{-C_{1}\left(T-T_{g}\right)}{C_{2}+T-T_{g}}
$$

によるフィッティングを試みたところ， $T_{g}$ 以上では見事に フィッティングできた.$T_{g}$ 以下でのWLF式からの逸脱は $T_{g}$ 以上から以下への緩和モードの変化 ${ }^{28)}$, 29) により説明できる であろう．Fig.4で特に注目すべき点は， $E\left(t / a_{T}\right)$ においてガラ ス転移領域とゴム状平坦領域の間に明確な屈曲が見られるの に対して,$\Delta n\left(t / a_{T}\right) / \varepsilon$ においては光の屈曲が見られずに連続 的に緩和していることである。

応力は「歪み (distortion)」と「配向 (orientation)」の寄 与により生じると考えられている17, 30, 31).$E\left(t / a_{T}\right)$ に見られる ガラス転移領域とゴム状平坦領域の間の屈曲は, ガラス領域 で支配的で高い弾性率を発現させる「歪み」が応力緩和中に ガラス転移領域て解消し, 兴の後のゴム状平坦領域において は低い弾性率しか発現させない「配向」の寄与が支配的にな ることによると考えられる . 弚れに対して, $\Delta n\left(t / a_{T}\right) / \varepsilon$ では ガラス転移領域とゴム状平坦領域の間の屈曲が見られなかっ たのは, 複屈折では「配向」の寄与が支配的でガラス転移領 域からゴム状平坦領域に至るまで「配向」の緩和が連続的に 進行することによると考えられる。

Fig.2からFig.4の結果の中には $T_{g}$ 以下て数時間から十数時 間応力・複屈折緩和測定を行って得られたものがあるが, 乥 の長時間の緩和測定中にphysical agingが生じると考えられ る . physical agingについてはDSC測定の結果から論じること ができる .

quenched試料を $135^{\circ} \mathrm{C}\left(<T_{g}\right)$ て緩和測定し, 測定後の試 料について温度变調DSC測定を行って, 得られた熱量曲線の 非可逆成分から吸熱ピークを求めた結果をFig.5に示す. 同 図にquenched試料を $135^{\circ} \mathrm{C} て$ 熱処理 (annealed) することに

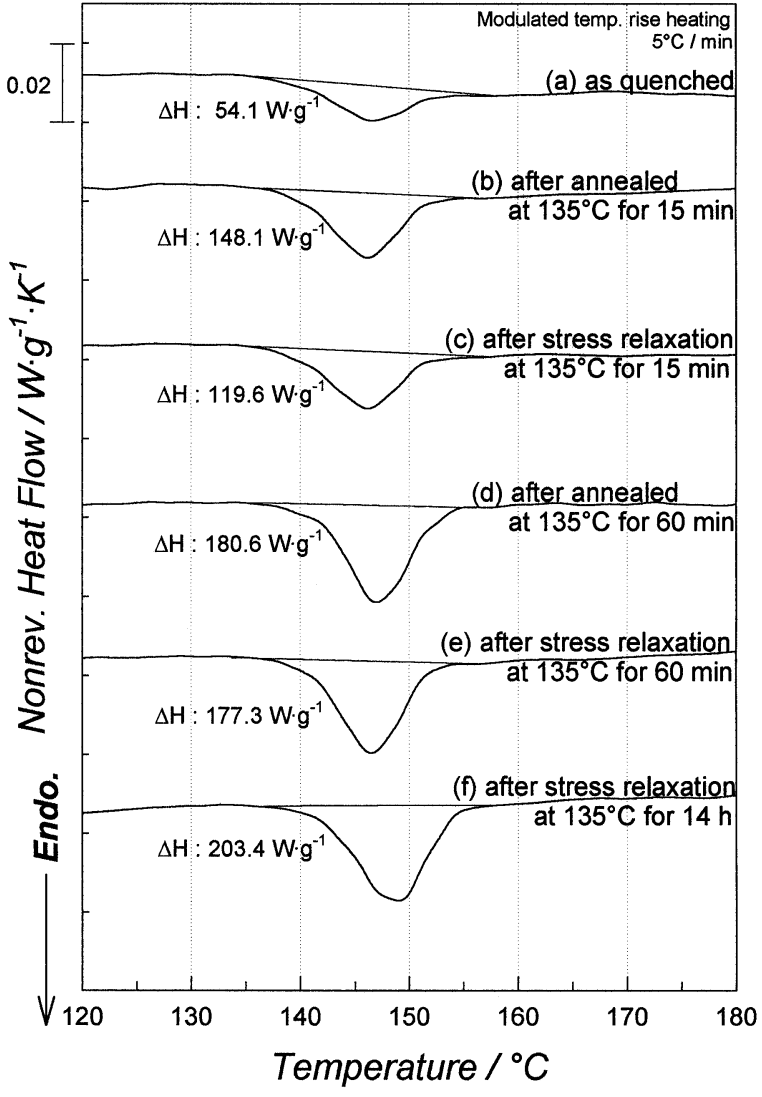

Fig.5 Nonreversing heat flow curves from oscillated DSC measurement for various PC samples; The as-quenched sample (a) was annealed at $135^{\circ} \mathrm{C}$ for $15 \mathrm{~min}$ (b) and $60 \mathrm{~min}$ (d). It was also subjected for stress relaxation measurement at $135^{\circ} \mathrm{C}$ for 15 $\min (\mathrm{c}), 60 \mathrm{~min}(\mathrm{e})$ and $14 \mathrm{~h}(\mathrm{f})$.

よってphysical agingさせたものについての同樣の結果も示 す . 緩和測定時間が長くなるに伴い, 吸熱ピークが高温にシ フトして , ピーク面積は増大している.この吸熱ピークは $T_{g}$ 以下での熱処理により，緩和されたエンタルピーがDSCの昇 温中に $T_{g}$ 付近で回復することにより現れる．弚の面積はエ ンタルピー緩和が進行するほど, つまりはphysical agingが進 行するほど大きい(12)．このことから，応力・複屈折緩和測 定中にphysical agingが進行していることは明らかである.ま た , これらの吸熱ピーク面積とピーク位置は, 同じ温度で同 じ時間熱処理のみを行ったannealed試料の弚れらとの間にほ とんど違いが見られない．これより緩和測定の際の一軸伸長 の微少変形 (約1\%) はエンタルピー緩和にほとんど影響を 及ぼさないと考えられる。

Fig.4に示した応力・複屈折緩和測定を行った後の試料の 全熱量曲線をFig.6に示す . $140^{\circ} \mathrm{C}$ 以下で緩和測定した後の試 料では吸熱ピークか現われ，この吸熱ピークは低温ほど大き い. $140^{\circ} \mathrm{C}$ 以下での緩和測定中にphysical agingが淮行し, 关 の進行の度合いは低温ほど大きいと考えられる . Fig.4に示 したように，応力緩和曲線と複屈折緩和曲線は光れ光れ良好 に重ね合わせができた .これは緩和測定中にphysical agingが 進行していると考えられる $140^{\circ} \mathrm{C}$ 以下の低温で測定された緩 和曲線と, より高温で測定された緩和曲線の重ね合わせが良 好であることを意味する．つまり応力・複屈折緩和挙動への 


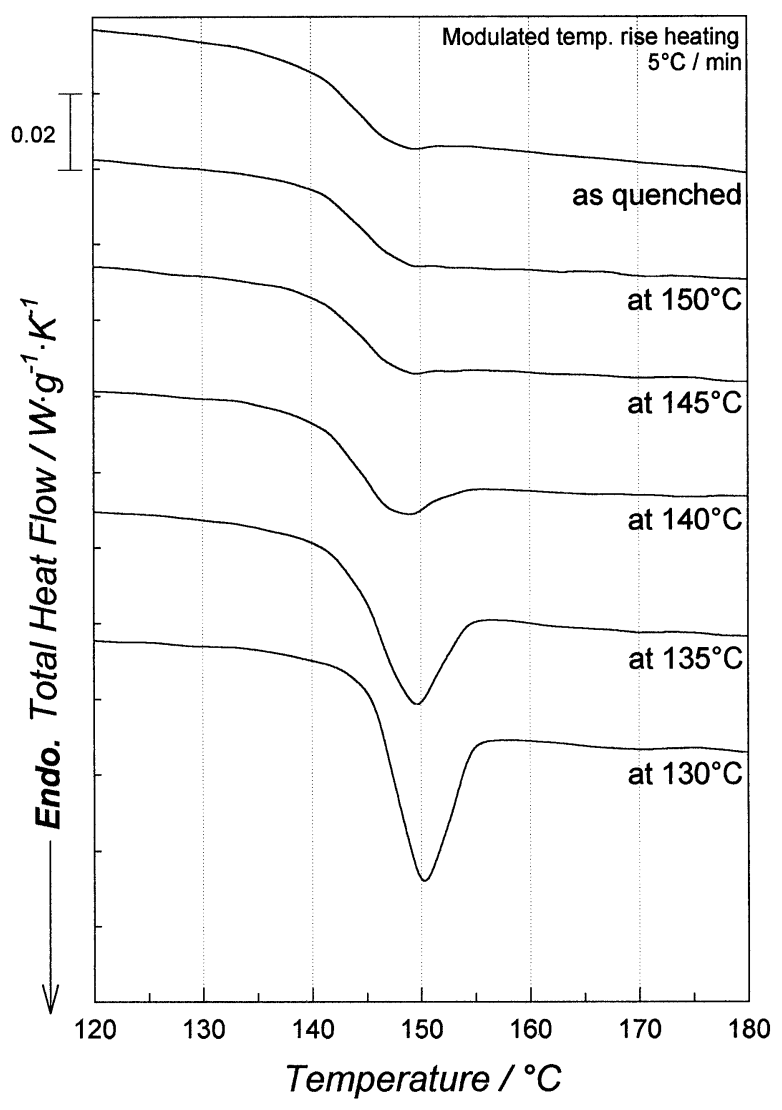

Fig.6 Total heat flow curves of oscillated DSC for an as-quenched PC and PC samples after stress relaxation measurement at various temperatures.

agingの影響はほとんどないと考えられる .

$127^{\circ} \mathrm{C}$ で85時間physical agingさせた試料の応力緩和と複屈 折緩和の重ね合わせ曲線 $E\left(t / a_{T}\right)$ と $\Delta n\left(t / a_{T}\right) / \varepsilon$ をFig.7に示す . $T_{g}$ 以下で測定された緩和曲線, 特に複屈折緩和曲線はガラ ス転移領域付近で良好な重ね合わせができないことがわかっ た.さらに, quenched試料では見られなかったガラス転移 領域とゴム状平坦領域の間での屈曲が見られた .この屈曲は 低温ほど大きい. なお, ガラス転移領域で重なり合わなかっ た複屈折緩和曲線がゴム状平坦領域で再び重なり合うことは 興味深い .

aged試料を, 光のaging温度 $\left(127^{\circ} \mathrm{C}\right)$ よりも高温の $135^{\circ} \mathrm{C}$ で緩和測定した後の温度変調DSC吸熱ピークを求めた結果を Fig.8に示す. 同図にaged試料を同温度で熱処理した (rejuvenated) ものについての同樣の結果も示す. 熱処理時 間や緩和測定時間が長くなるに伴い吸熱ピークが低温にシフ トして, 弚の面積は小さくなっている.これは, aged試料を そのaging温度よりも高温におくと, agingによって緩和した エンタルピーの回復, つまり rejuvenation ${ }^{32 \sim 34)}$ が生じた結果 であると考えられる . なお, Fig.5の結果と同樣に, 同じ温 度・同じ時間で緩和測定をした試料と熱処理のみをした試料 の間に, ピーク面積やピーク位置の違いはほとんど見られな かった .これより複屈折緩和測定の際の一軸伸長の微少変形 がエンタルピー緩和へ及ぼす影響はほとんどないと考えら れる .

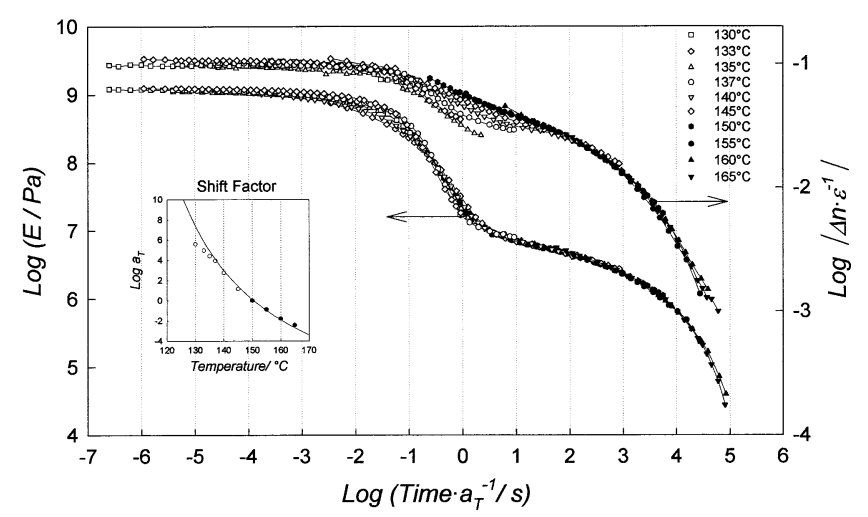

Fig.7 Master curves of relaxation modulus $E\left(t / a_{T}\right)$ and relaxation birefringence $\Delta n\left(t / a_{T}\right) / \varepsilon$ for $\mathrm{PC}$ aged at $127^{\circ} \mathrm{C}$ for $85 \mathrm{~h}$; reduced at $150^{\circ} \mathrm{C}$.

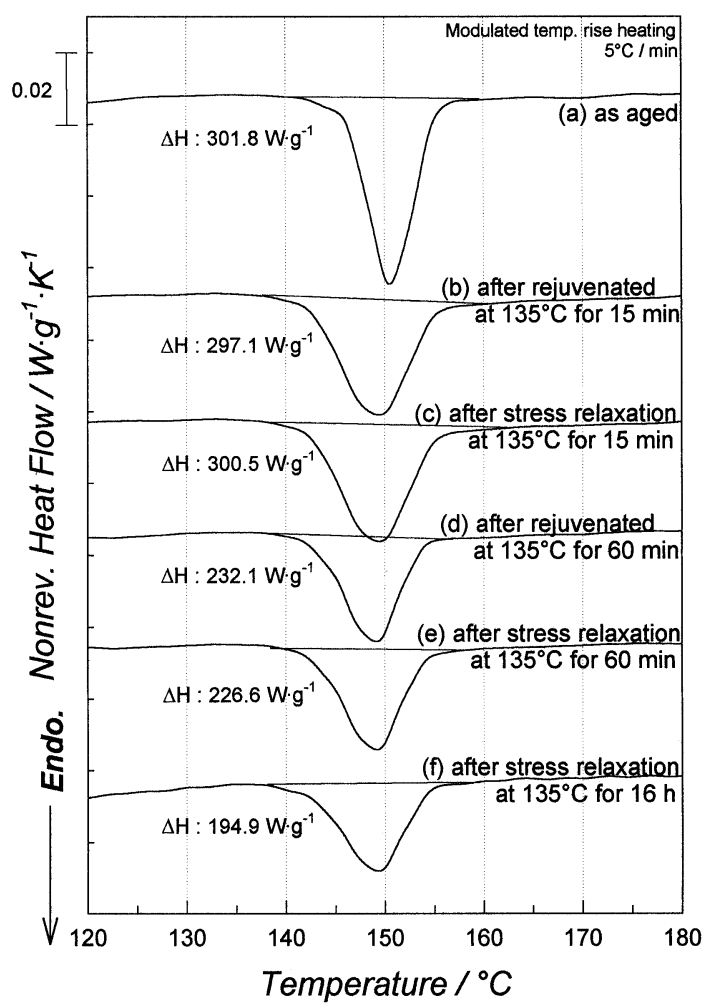

Fig.8 Nonreversing heat flow curves from oscillated DSC for various PC samples; PC aged at $127^{\circ} \mathrm{C}$ for $85 \mathrm{~h}$ (a) was rejuvenated at $135^{\circ} \mathrm{C}$ for $15 \mathrm{~min}$ (b) and $60 \mathrm{~min}$ (d). It was also subjected for stress relaxation measurement at $135^{\circ} \mathrm{C}$ for $15 \mathrm{~min}(\mathrm{c}), 60 \mathrm{~min}$ (e) and $16 \mathrm{~h} \mathrm{(f).}$

応力・複屈折緩和測定した試料の吸熱ピーク面積は高温で 測定したものほど小さくなっている (Fig.9) . また , Fig.5の quenched試料を $135^{\circ} \mathrm{C} て ゙ 14$ 時間応力緩和測定をした後の吸熱 ピーク面積と，Fig.8のaged試料を $135^{\circ} \mathrm{C} て ゙ 16$ 時間応力緩和測 定をした後の吸熱ピーク面積はほとんど一致している .これ と同樣に130,140,145, 150C においてquenched試料と aged試料を緩和測定した後の吸熱ピーク面積はほぼ一致して いた (Figs.6, 9) . とれらの結果から，aged試料をより高温で 応力・複屈折緩和測定に供するとagingにより緩和されたエ ンタルピーが応力・複屈折緩和測定中に測定 (熱処理) 温度 
に対応した，より高い平衡エンタルピー值を目指して回復す ると考えられる .

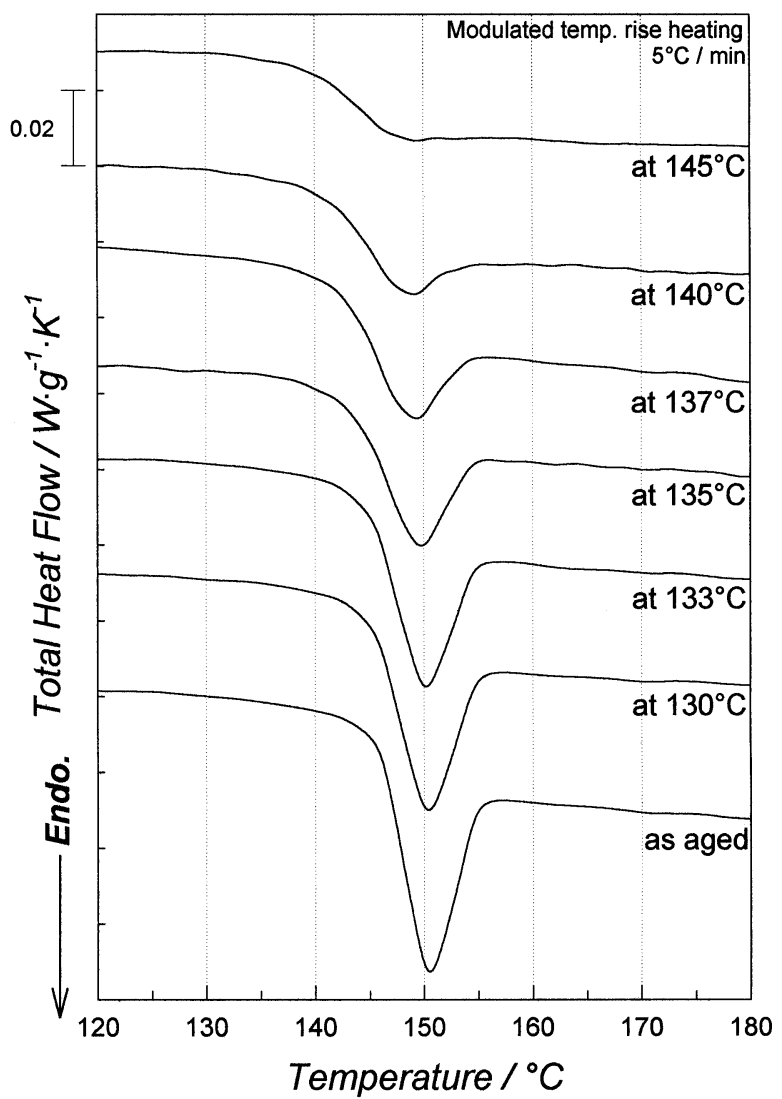

Fig.9 Total heat flow curves of oscillated DSC for an as-aged PC and PC samples after stress relaxation measurement at various temperatures.

Fig.7に示したように, aged試料における緩和曲線はガラ ス転移領域付近で良好な重ね合わせができなかった .これは physical agingにより試料か緻密化すること,ささらに緩和測定 中にrejuvenationが生じることによる複雑な構造変化に起因 していると考えられる. 弚の構造変化の影響か特に複屈折緩 和に敏感に現れる理由については, 現時点では明確な説明を することができないが, 高温の緩和測定においては熱履歴の ほとんどが緩和初期で解消されてquenched試料に近い状態 が達成された後に緩和するために良好な重ね合わせが可能で あると考えられる .

\section{4. 結 論}

quenched試料では応力・複屈折緩和曲線がともに良好に 時間・温度の重ね合わせができたことから，緩和測定中の physical agingの影響はほとんど見られないと考えられる. 光 れに対して, aged試料における緩和曲線, 特に複屈折緩和曲 線はガラス転移領域において良好な重ね合わせができないこ とがわかった .これはagingによる緻密化と, 測定中の rejuvenationによるものと考えられる.さらに, rejuvenation 速度は (緩和測定) 温度により異なるはずであり，これらが
レオロジー的複雑性を生む原因になっていると考えられる． このレオロジー的複雑性は, 何をもって高分子 (例えばPC) の緩和曲線，ひいては緩和スペクトルとするかの問題につな がる．つまり，PCのquenched試料をPCとするのが妥当であ ると考えるべきであろうか? 通常, quenched試料の熱歪 みを除去するために $T_{g}$ 近傍で長時間熱処理した後の試料を 緩和実験に用いるのが良いとされている．さらに熱処理後は 長時間をかけて室温まで徐冷するのが良いとされている ここ のような操作を「ていねい」にすればするほど, physical agingを進行させた試料ということになる．quenched試料を そのまま用いることで妥協すべきであろうか? physical aging が無視できる範囲で熱歪みを極力消去すべく，エンタルピー 緩和の度合いや熱歪みを厳密にモニターした試料以外は応力 緩和実験に用いるべきではないと考えるべきであろうか?今 後の検討課題である.

\section{参考文献}

1) Ferry JD, "Viscoelastic Properties of Polymers", 3rd ed, (1980), Wiley, New York, N.Y.

2) Doi M and Edwards SF, "The Theory of Polymer Dynamics", (1986), Clarendon, Oxford.

3) Rouse PE, J Chem Phys, 21, 1272 (1953).

4) Lin YH, Macromolecules, 19, 159, 168 (1986).

5) Lin YH, Macromolecules, 29, 5200 (1996).

6) Kovacs AJ, Aklonis JJ, Hutchinson JM, Ramos AR, J Polym Sci, Polym Phys Ed, 17, 1097 (1979).

7) Berens AR, Hodge IM, Macromolecules, 15, 756 (1982).

8) Hodge IM, J Non-Cryst Sol, 169, 211 (1994).

9）系山 國義, 日本レオロジー学会誌，22, 90 (1994).

10) 系山 國義, 日本レオロジー学会誌, 23, 131 (1995).

11) Yoshida H, Thermochim Acta, 226, 119 (1995).

12) Takahara K, Saito H, Inoue T, Polymer, 40, XXX (1999).

13) Struik LCE, "Physical Aging in Amorphous Polymers and other Materials", (1978), Elsevier, Amsterdam.

14) Tant MR, Wilkes GL, Polym Eng Sci, 21, 874 (1981).

15) Kobayashi $Y$, Zhong W, Meyer EF, McGervey JD, Jamieson AM, Simha R, Macromolecules, 22, 2303 (1989).

16) Hill AJ, Jones PL, Polym Eng Sci, 30, 762 (1990).

17) Read BF, Polym Eng Sci, 23, 835 (1983).

18) Saito $\mathrm{H}$, Takahashi $\mathrm{M}$, and Inoue $\mathrm{T}$, Macromolecules, 24, 6536 (1991).

19) Saito H, Miyashita H, Inoue $T$, Macromolecules, 25, 1824 (1992).

20) Shimo T, Nagasawa M, Macromolecules, 25, 5026 (1992).

21) Hwang EJ, Inoue T, Osaki K, Polymer, 34, 1661 (1993).

22) 岡浩孝, 黄義正, 井上正志, 尾崎邦宏, 日本レオロ ジー学会誌, 21, 86 (1993).

23) Osaki $\mathrm{K}$, Inoue $\mathrm{T}$, Hwang EJ, Okamoto $\mathrm{H}$, Takiguchi $\mathrm{O}, J$ Non-Cryst Sol, 172-174, 838 (1994).

24）井上正志, 尾崎邦宏, 高分子論文集, 53, 602 (1996). 
25) Osaki K, Inoue T, Macromolecules, 29, 7622 (1996).

26) Reading M, Elliott D, Hill VJ, J Thermal Anal, 40, 949 (1993).

27) Boller A, Schick C, Wunderlich B, Thermochim Acta, 266, 97 (1995).

28) Hoffman A, Kremer F, Fischer EW, Schonhals A, "Disorder Effects on Relaxation Process, Glass, Polymer, Proteins", Richter R, Blumen A ed, (1994), Springer, Berlin Chap. 10.

29) Perez J, Cavaille JY, J Non-Cryst Sol, 172-174, 1028 (1994).
30) Yannas IV, Luise RR, J Macromol Sci, Phys, B21, 443 (1982).

31) Koenen JA, Heise B, Killian HG, J Polym Sci, Polym Phys Ed, 27, 1235 (1989).

32) McKenna GB, Kovacs AJ, Polym Eng Sci, 24, 1138 (1984).

33) McKenna GB, Santore MM, Lee A, Duran RS, J Non-Cryst Sol, 131-133, 497 (1991).

34) Bauwens-Crowet C, Bauwens JC, J Non-Cryst Sol, 131-133, 505 (1991). 